\title{
Pediatric Research: Past Progress and Future Directions
}

To the Pediatric Research readership,

On behalf of the editors and staff of Pediatric Research, please accept our warmest wishes for a prosperous and productive 2006 !

As we embark on the New Year, I would like to bring you up to date on some changes you will see in the journal. The European Editorial Board will undergo a change this year as Jean-Christophe Mercier completes his term of service to the journal, and Petra Hüppi assumes the European board leadership role.

During the past five years, Professor Mercier served the journal brilliantly as European Chief Editor. Professor Mercier and his board members have provided excellent leadership in Europe and made significant contributions to the journal. It has been a great pleasure to work with Professor Mercier and his colleagues, and as they take their leave from editorial service to the journal, I would like to thank them for their dedication and partnership in our collective endeavors.

Petra Hüppi, the incoming European Chief Editor, along with her editorial board, will join the existing North American board as we move toward the creation of an integrated board of editors. As we establish this new integrated partnership, I would like to take this opportunity to welcome Professor Hüppi and the new board members to the journal.

In addition to integrating the North American and European Editorial boards, we recently formulated a Board of Consulting Editors to complement the existent scientific expertise of the editorial board. We are most excited about the prospect of this international group of editors, who will assist the journal, as we continue to work for the benefit of all investigators, who are committed to improving children's health through research.

During the past two years, we made several changes to the overall goal of improving the quality of the journal. To improve the handling of manuscripts, we established an on-line manuscript submission system to streamline the peer review process, and implemented a two-tier process to assure that the editorial (tier 1) and peer-review (tier 2) processes are accomplished in a timely manner. To increase readership to the journal, we added an Editor's focus page to highlight notewor- thy articles appearing in each issue, and commenced publication of an annual review issue to bring cutting-edge topics of interest to our readers.

We recently introduced an open-archive policy that provides free access to articles published in the journal six months after publication, to make the content of our journal more accessible to investigators. This time frame is substantially less than the 12-month open-archive policy encouraged by the National Institutes of Health. We shall continue to keep pace with the rapid changes occurring in the publishing world, with the goal of working toward a strategy to attain full open access for the journal, while balancing the need to produce a quality publication.

Beginning this year, the Instructions to Authors have been modified to reflect changes in journal policy to make information pertaining to particular studies more accessible to other investigators, as well as to the public at large. These policy changes include, 1) registration of clinical trials at www. ClinicalTrials.gov; and, 2) the deposit of sequence and DNA micro-array or protein data into national databanks.

Last, but not least, we initiated a virtual journal. The virtual journal serves to contain the length of articles by allowing methodological details, lengthy tables, and/or figures to be placed on-line as a complement to the manuscript text published in print and on-line. The International Pediatric Research Foundation shares the same vision as they continue to provide oversight to the journal.

We are looking forward to a great year for the journal, and we are excited about working with our new editorial colleagues. In closing, I would like to thank the reviewers for their assistance and the authors for their excellent contributions. It is the tireless hours that authors, reviewers and editors put into this endeavor that allows the journal to serve you, our readers.

Thank you and very best wishes from all of us at Pediatric Research.
Sherin U. Devaskar, M.D. Editor in Chief 